\title{
ANALISIS FAKTOR-FAKTOR YANG MEMPENGARUHI ALOKASI WAKTU KERJA DAN KONTRIBUSINYA TERHADAP PENDAPATAN RUMAH TANGGA NELAYAN \\ (Kasus Nelayan Malabero Kecamatan Teluk Segara Kota Bengkulu)
}

\author{
Muhamad Nurung ${ }^{1}$ \\ Mustopa Romdhon ${ }^{1}$ \\ Mandrik $^{2}$
}

\begin{abstract}
Oceanic sector development basically represent an process to alter potency exist in sea region become an worthwhile to society. In general, fisherman in Bengkulu province is traditional fisherman owning simple equipments, capital a few and way of simple production. Fisherman also face the condition of less beneficial environment like situation waving sea enough strength, weather, and dicey climate, so that influence arrest time allocation. Thereby, fisherman look for alternative work utilize to fulfill requirements of his family.Research targets is knowing factors influencing in working allocation at the fishery catch sector and the outside, knowing how big contribution of the fisherman allocation work, knowing how big contribution of the fisherman time work at the fishery catch sector and the outside toward totalize in working, and knowing how big contribution of the fisherman earnings in working at the fishery catch sector and outside toward totalize earnings.The research location in Sub-District of Malabero District of Teluk Segara at Bengkulu City.
\end{abstract}

Key words: contribution, time work, fisherman

\section{PENDAHULUAN}

Pembangunan sektor kelautan pada dasarnya merupakan suatu proses untuk mengubah potensi yang ada di wilayah laut menjadi suatu yang bermanfaat bagi masyarakat. Indonesia dikaruniai Tuhan dengan lautan yang lebih luas dari daratan. Kira-kira dua per tiga wilayah Indonesia adalah perairan laut yang terdiri dari laut pesisir, laut lepas, teluk dan selat. Keseluruhannya adalah bagian dari perairan teritorial dengan luas sekitar 3,1 juta $\mathrm{Km}^{2}$. selain itu, Indonesia juga memiliki hak pengelolaan dan pemanfaatan ikan di Zona Ekonomi Ekslusif (ZEE), yaitu perairan yang berada 12 hingga 200 mil dari garis pantai titik terluar kepulauan Indonesia. Luas ZEE sekitar 2,7 juta $\mathrm{Km}^{2}$, dengan demikian Indonesia dapat memanfaatkan sumber-daya alam hayati dan non-hayati di perairan yang luasnya sekitar 5,8 juta $\mathrm{Km}^{2}$. Selain sumberdaya perairan, Indonesia juga memiliki 17.508 
pulau yang menjadikan Indonesia sebagai negara kepulauan yang besar di dunia (Nikijuluw. 2002)

Sebagai salah satu bagian dari wilayah Republik Indonesia Propinsi Bengkulu dengan luas wilayah $\pm 1.978 .870 \mathrm{Ha}$, merupakan daerah yang berbatasan dengan samudera Indonesia dan memiliki pantai sepanjang $\pm 550 \mathrm{Km}$ (Kemaja, 1992 dalam Pramudyasmoro, 1993), tentunya cukup banyak penduduk yang menggantungkan hidupnya pada laut. Nelayan tradisional ini pada umumnya memiliki peralatan yang sederhana, permodalan yang lemah dan cara produksi yang sederhana. Nelayan juga menghadapi kondisi lingkungan yang kurang menguntungkan seperti keadaan gelombang laut cukup kuat, cuaca dan iklim yang tidak menentu sehingga mempengaruhi alokasi waktu penangkapan.

Pengamatan terhadap usaha nelayan disektor perikanan tangkap di daerah Pasar Pantai Kecamatan Teluk Segara Kota Bengkulu diduga bahwa alokasi waktu kerja dipengaruhi oleh faktor-faktor sosial ekonomi seperti : umur, pendidikan, pengalaman kerja, jumlah tanggungan keluarga, jenis pekerjaan, modal kerja dan kepemilikan asset. Keberadaan faktor sosial ekonomi tersebut memotivasi nelayan untuk memanfaatkan waktu luang sebagai salah satu upaya untuk membantu meningkatkan pendapatan keluarga.

Bekerja diluar sektor perikanan tangkap mempunyai makna apabila sektor tersebut dapat memberikan kontribusi terhadap pendapatan rumah tangga dan ditentukan oleh waktu luang yang dimiliki tiap nelayan dalam sektor perikanan tangkap. Dengan demikian total waktu yang dimiliki nelayan ditentukan dari bekerja dalam sektor perikanan tangkap, luar sektor perikanan tangkap dan waktu luang. Maka penulis ingin menganalisa faktor sosial ekonomi apa saja yang mempengaruhi alokasi waktu kerja nelayan yang bekerja baik didalam maupu diluar sektor perikanan tangkap yang digelutinya dan seberapa besar 
kontribusinya terhadap pendapatan rumah tangga nelayan di lokasi tersebut diatas. Adapun maksud dari penelitian ini hádala untuk menganalisa faktor-faktor yang mempengaruhi alokasi waktu kerja dalam sektor perikanan tangkap dan waktu kerja diluar sektor perikanan tangkap,besar kontribusi waktu kerja nelayan dari bekerja dalam sektor perikanan tangkap dan diluar sektor perikanan tangkap terhadap total waktu verja dan untuk menganalisa berapa besar kontribusi pendapatan nelayan dari bekerja dalam sektor perikanan tangkap dan diluar sektor perikanan tangkap tarhadap total pendapatan.

\section{METODOLOGI PENELITIAN}

Lokasi penelitian ditetapkan secara sengaja (puposive) di Daerah Pasar Pantai Kota Bengkulu. Populasinya adalah nelayan pemilik alat tangkap, yang aktif melaut dan juga mengalokasikan waktu kerjanya pada kegiatan ekonomi diluar sektor perikanan tangkap. Pengambilan sampel dilakukan dengan cara sensus, nelayan yang dimaksud pada bulan September-Oktober 2006 ada sebanyak 32 kepala keluarga. Jadi respondennya adalah 32 orang. September-Oktober 2006 ada sebanyak 32 kepala keluarga. Jadi respondennya adalah 32 orang.

\section{Model Pendugaan Faktor-faktor yang Mempengaruhi Alokasi Waktu Kerja}

Analisis yang digunakan adalah regresi linier berganda yang ditransformasi ke dalam bentuk logaritma natural (ln). Secara matematis ( Supranto, 1990) :

\section{Model Alokasi Waktu Kerja Model Alokasi Waktu Kerja Dalam Sektor Perikanan Tangkap}

Alakosi waktu kerja nelayan dalam sektor perikanan tangkap merupakan fungsi dari umur, pendidikan formal, pengalaman melaut, jumlah tanggungan keluarga, modal kerja penangkapan dan kepemilikan asset. 
$\operatorname{LnY}_{\mathrm{a}}=\mathrm{a}_{0}+\mathrm{a}_{1} \ln \mathrm{X}_{1}+\mathrm{a}_{2} \ln \mathrm{X}_{2}+\mathrm{a}_{3} \ln \mathrm{X}_{3}+\mathrm{a}_{4} \ln \mathrm{X}_{4}+\mathrm{a}_{5} \ln \mathrm{X}_{5}+\mathbf{a}_{6} \ln \mathrm{X}_{6}+\mathrm{U}_{1}$

Dimana:

$\ln \mathrm{Y}_{\mathrm{a}}=$ Alokasi waktu kerja dalam sektor perikanan tangkap (jam/bln)

$\ln \mathrm{X}_{1}=\operatorname{Umur}(\mathrm{th})$

$\ln \mathrm{X}_{2}=$ Pendidikan formal (th)

$\ln X_{3}=$ Pengalaman melaut (th)

$\ln \mathrm{X}_{4} \quad=$ Jumlah tanggungan keluarga (orang)

$\ln \mathrm{X}_{5}=$ Modal kerja penangkapan (Rp)

$\ln X_{6}=$ Kepemilikan asset seperti perahu, mesin dan alat tangkap (Rp)

$\mathrm{a}_{0} \quad=$ Intercept

$\mathrm{a}_{\mathrm{i}} \quad=$ Parameter dugaan $(\mathrm{i}=1,2,3,4,5)$

$\mathrm{u}_{1} \quad=$ Kesalahan pengganggu

2. Model Alokasi Waktu Kerja Luar Sektor Perikanan Tangkap.

Alakosi waktu kerja nelayan luar sektor perikanan tangkap merupakan fungsi dari umur, pengalaman kerja, jumlah tanggungakeluarga dan modal kerja diluar sektor perikanan tangkap.

$\operatorname{LnY}_{b}=b_{0}+b_{1} \ln X_{1}+b_{2} \ln X_{2}+b_{3} \ln X_{3}+$

$$
b_{4} \ln X_{4}+D+U_{2} \ldots \ldots(1)
$$

Dimana: $\mathrm{n}$

$\ln \mathrm{Y}_{\mathrm{b}}=$ Alokasi waktu kerja luar sektor perikanan tangkap $(\mathrm{jam} / \mathrm{bln})$

$\ln \mathrm{X}_{1}=$ Umur (th)

$\ln \mathrm{X}_{2} \quad=$ Pengalaman kerja (th)

$\ln X_{3}=$ Jumlah tanggungan (orang)

$\ln \mathrm{X}_{4}=$ Modal kerja luar perikanan $(\mathrm{Rp})$

$\mathrm{D}=$ Jenis pekerjaan sampingan 


$$
\begin{array}{ll} 
& \mathrm{D}=1 \text { Jenis pekerjaan mengolah } \\
& \mathrm{D}=0 \text { Jenis pekerjaan diluar } \\
\mathrm{b}_{0} \quad=\text { Intercept } \\
\mathrm{b}_{\mathrm{i}} \quad=\text { Parameter dugaan }(\mathrm{i}=1,2,3,4) \\
\mathrm{u}_{2} \quad=\text { Kesalahan pengganggu }
\end{array}
$$

Untuk mengetahui apakah variabel bebas memiliki pengaruh secara bersama-sama terhadap variabel terikat maka dilakukan uji F pada tingkat kepercayaan tertentu $(\alpha=95$ $\%)$.

Hipotesis yang akan diuji adalah sebagai berikut :

$$
\text { Ho : bi }=0 \quad \text { Ha : paling tidak ada salah satu dari bi }>0
$$

Uji F dirumuskan (Drapper, 1992):

dimana :

$$
\mathrm{F}_{\text {hitung }}=\frac{R^{2} /(k-1)}{\left(1-R^{2}\right) /(n-k)}
$$

$$
\begin{aligned}
& \mathrm{R}_{2}=\text { Koefisien determinan } \\
& \mathrm{n}=\text { Jumlah sampel } \\
& \mathrm{k}=\text { Jumlah variabel bebas }
\end{aligned}
$$

Adapun kriteria pengujian adalah sebagai berikut :

Ho diterima jika $\mathrm{F}_{\text {hitung }} \leq \mathrm{F}_{\text {tabel }}$, artinya secara bersama-sama variabel bebas tidak berpengaruh terhadap alokasi waktu kerja nelayan dalam sektor perikanan tangkap dan luar sektor perikanan tangkap.

Ha diterima jika $\mathrm{F}_{\text {hitung }}>\mathrm{F}_{\text {tabel }}$, artinya secara bersama variabel bebas berpengaruh terhadap alokasi waktu kerja nelayan dalam sektor perikanan

tangkap dan luar sektor perikanan tangkap.

Untuk melihat signifikasi masing-masing variabel bebas terhadap variabel tidak bebas digunakan Uji -t, dengan tingkat kepercayaan tertentu $\alpha=95 \%$. 
Hipotesis yang akan diuji adalah sebagai berikut :

Ho : bi $=0$

Ha : paling tidak ada salah satu dari $b i \neq 0$

Uji t dirumuskan (Drapper, 1992):

$$
t_{\text {hitung }}=\frac{b i}{S b i}
$$

dimana :

$\mathrm{b}_{\mathrm{i}} \quad=$ koefisien variabel bebas

Sbi $=$ Standar error (kesalahan baku) dari masing-masing variabel bebas .

\section{Model Kontribusi Alokasi Waktu Kerja Didalam Maupun Diluar Sektor Perikanan Tangkap}

Untuk mendapatkan seberapa besar kontribusi alokasi waktu kerja nelayan, maka terlebih dahulu perlu diketahui total waktu kerja yang dicurahkan. Total alokasi waktu kerja nelayan merupakan fungsi identitas, yang merupakan penjumlahan antara waktu kerja dalam sektor perikanan tangkap dan diluar sektor perikanan tangkap. Secara matematis dapat ditulis sebagai berikut :

$\mathbf{Y} \mathbf{L}=(\mathbf{Y a})+(\mathbf{Y b})$

Dimana:

YL $=$ Total alokasi waktu kerja (jam/bln)

$(\mathrm{Ya})=$ Alokasi waktu kerja dalam sektor perikanan tangkap $(\mathrm{jam} / \mathrm{bln})$

$(\mathrm{Yb})=$ Alokasi waktu kerja diluar sektor perikanan tangkap $(\mathrm{jam} / \mathrm{bln})$

Selanjutnya, untuk mengetahui besarnya kontribusi alokasi waktu kerja nelayan didalam maupun diluar sektor perikanan tangkap digunakan analisa deskriptif dan dinyatakan dalam persentase $(\%)$.

Alokasi waktu kerja dalam sektor perikanan tangkap $=\stackrel{Y_{a}}{X} 100 \%$ 
Alokasi waktu kerja luar sektor perikanan tangkap $=\frac{\mathrm{Y}_{\mathrm{b}}}{\mathrm{Y}_{\mathrm{L}}} \mathrm{X}$ 100\%

Model Kontribusi Pendapatan Didalam Maupun Diluar Sektor Perikanan Tangkap

Secara umum besarnya pendapatan kepala rumah tangga dapat dirumuskan sebagai berikut :

$$
\begin{aligned}
& \mathrm{I}=\mathrm{TR}-\mathrm{TC} \\
& \mathrm{TR}=\mathrm{Y} \cdot \mathrm{Py} \\
& \mathrm{TC}=\mathrm{FC}+\mathrm{VC}
\end{aligned}
$$

dimana:

$\mathrm{I} \quad=$ Pendapatan $(\mathrm{Rp} / \mathrm{bln})$

$\mathrm{TR}=$ Total penerimaan $(\mathrm{Rp} / \mathrm{bln})$

$\mathrm{TC}=$ Total biaya $(\mathrm{Rp} / \mathrm{bln})$

$\mathrm{Y}=\mathrm{Jumlah}$ total produk $(\mathrm{Kg})$

Py = Harga jual $(\mathrm{Rp} / \mathrm{kg})$

$\mathrm{FC}=$ Biaya tetap $(\mathrm{Rp})$

$\mathrm{VC}=$ Biaya variabel $(\mathrm{Rp})$

Untuk mengukur besarnya kontribusi pendapatan kepala rumah tangga nelayan yang bekerja di dalam maupun di luar sektor perikanan tangkap terhadap total pendapatan rumah tangga nelayan digunakan perhitungan yang berpedoman pada pendapatan kepala rumah tangga nelayan dari bekerja dalam sektor perikanan tangkap dan luar kegiatan sektor perikanan tangkap dengan total pendapatan rumah tangga dikalikan $100 \%$ kemudian dianalisa secara deskriptif dan di nyatakan dalam persentase.

$\mathrm{I}_{\mathrm{a}}$

Kontribusi pendapatan dari bekerja dalam sektor perikanan tangkap $=\longrightarrow \mathrm{X} 100 \%$ 


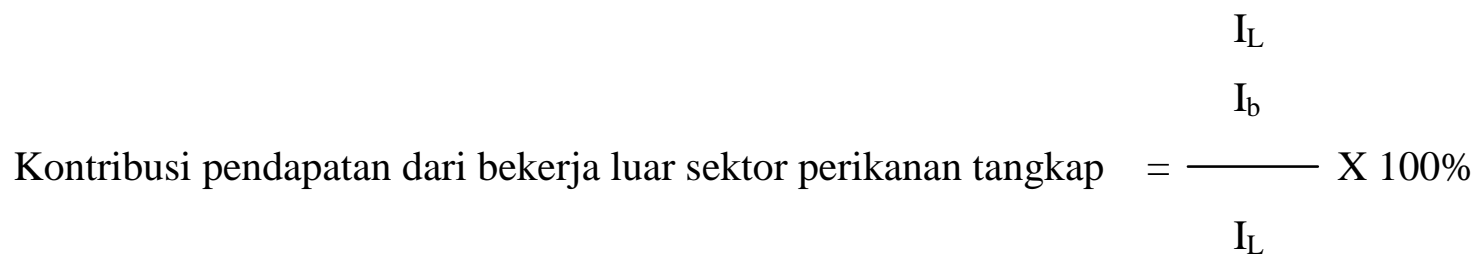

Ket:

$\left(\mathrm{I}_{\mathrm{L}}\right)=$ Total pendapatan $(\mathrm{Rp} / \mathrm{bln})$

$(\mathrm{Ia})=$ Pendapatan dalam sektor perikanan tangkap $(\mathrm{Rp} / \mathrm{bln})$

$(\mathrm{Ib})=$ Pendapatan luar sektor perikanan tangkap $(\mathrm{Rp} / \mathrm{bln})$

\section{HASIL DAN PEMBAHASAN}

\section{Analisis Faktor-Faktor Yang Mempengaruhi Alokasi Waktu Nelayan Dalam Kegiatan Sektor Perikanan Tangkap.}

Sebelum membahas mengenai model pendugaan faktor-faktor yang mempengaruhi alokasi waktu kerja dalam perikanan tangkap ada beberapa hal yang perlu dijelaskan mengenai masalah multikolinearitas yang muncul pada analisis data. Menurut Gujarati, D (1978) multikolinearitas dapat diduga ketika besarnya koefisien kolerasi antar variabel bebas $(\mathrm{X})$ bernilai $\geq 0,7$. Pertama, peneliti mengeliminasi variabel umur (X1) pada analisis ini, karena terjadinya multikolinearitas dengan variabel pengalaman kerja (X3) dan nilai koefisien kolerasinya sebesar 0,77. Kedua, mengabungkan variabel modal kerja (X5) dengan variabel nilai asset (X6) menjadi variabel modal (X5+X6). Hal ini dilakukan karena sebelumnya juga terjadi multikolinearitas dengan nilai koefisien kolerasinya sebesar 0,87 . Walaupun telah dilakukan tindakan perbaikan dengan membagi data (X5 dan X6) dengan indeks harga konsumen, namun multikolinearitas masih saja terjadi. Hasil analisis selanjutnya ditunjukkan pada Tabel 7:

\begin{tabular}{lccc}
\hline \multicolumn{1}{c}{ Variabel Bebas } & Koefisien Regresi & Standar Error & T-hitung \\
\hline Pendidikan Formal $(\ln$ X2) & $-1,826$ & 0,043 & $-0,423$ \\
Pengalaman Melaut $(\ln$ X3) & $-3,675$ & 0,067 & $-0,546$ \\
Jumlah Tanggungan $(\ln$ X4) & $-2,871$ & 0,041 & $-0,695$
\end{tabular}




\begin{tabular}{lccc} 
Modal dalam Perikanan $(\ln X 5+\mathrm{X} 6)$ & 0,702 & 0,052 & $13,612 *$ \\
\hline Intersep & $-6,179$ & & \\
$\mathrm{R}^{2}$ & 0,903 & \\
$\mathrm{~T}$ tabel $(27, \alpha / 2,=0,025)$ & 2,052 & \\
F hitung & 62,998 & \\
F tabel $(27,4, \alpha=0,05)$ & 2,73 & & \\
\hline
\end{tabular}

Sumber : Analisis Data Primer

Ket* = Nyata taraf kepercayaan $95 \%$.

Jika Tabel diatas ditulis dalam bentuk regresi, maka model regresinya adalah :

$\operatorname{LnY}=-6,179-1,826 \operatorname{Ln} X 1-3,675 \operatorname{Ln} X 2-2,871 \operatorname{LnX} 3+0,702 \operatorname{LnX} 4+\mathrm{U} 1$

$(0,043) \quad(0,067)(0,041) \quad(0,052)$

Nilai $\mathrm{R}^{2}$ sebesar 0,903 artinya variasi dari naik turunnya alokasi waktu kerja didalam sektor perikanan tangkap dapat dijelaskan secara bersama-sama oleh pendidikan formal, pengalaman melaut, jumlah tanggungan keluarga dan modal dalam sektor perikanan tangkap sebesar 90,3 persen sedangkan sisanya sebesar 9,7 persen dijelaskan oleh variabel lain yang tidak dimasukkan dalam model persamaan regresi ini.

Hasil uji $\mathrm{F}$ menunjukkan $\mathrm{F}_{\text {-hitung }}$ lebih besar dari $\mathrm{F}_{\text {-tabel }}(62,998>2,73)$ sehingga Ho ditolak. Ini artinya secara bersama-sama variabel bebas berpengaruh nyata terhadap alokasi waktu kerja dalam sektor perikanan tangkap. Untuk uji t adalah sebagai berikut :

\section{a. Pendidikan Formal}

Koefisien regresi variabel pendidikan bernilai negatif yaitu $-1,826$ hal ini berarti bila pendidikan meningkat satu satuan maka dapat mempengaruhi penurunan alokasi waktu kerja dalam sektor perikanan tangkap sebesar 1,826 dengan asumsi faktor lain tetap. Namun pengaruh penurunan tersebut tidak nyata, hal ini ditunjukkan oleh nilai t hitung $(0,423)<\mathrm{t}$ tabel $(2,052)$ sehingga terima Ho.

Tidak berpengaruh nyatanya tingkat pendidikan formal terhadap alokasi waktu kerja nelayan ini, karena keterampilan menangkap ikan yang mereka miliki tidak dipelajari dari pendidikan formal tertentu, melainkan dapat diperoleh langsung di tempat bekerja. Hasil ini sejalan dengan hasil penelitian Irawan, A (2001) yang mengemukakan bahwa tidak 
berpengaruhnya pendidikan formal terhadap alokasi waktu kerja usaha perikanan karena peranannya relatif kecil.

\section{b. Pengalaman Melaut}

Koefisien regresi variabel pengalaman melaut bernilai negatif yaitu $-3,675$ hal ini berarti bila pengalaman melaut bertambah satu satuan maka dapat mempengaruhi penurunan alokasi waktu kerja dalam sektor perikanan tangkap sebesar 3,675 dengan asumsi faktor lain tetap. Namun pengaruh penurunan tersebut tidak nyata, hal ini ditunjukkan oleh nilai $t$ hitung $(0,546)<\mathrm{t}$ tabel $(2,052)$ sehingga terima Ho.

Kecakapan dalam menangkap ikan ini menjadikan nelayan paham betul dimana daerah operasi yang cocok pada saat-saat tertentu. Memang pengalaman dibutuhkan oleh nelayan, namun hal ini pengaruhnya sangat kecil dalam menurunkan alokasi waktu kerja nelayan. Hasil ini sejalan dengan penelitian yang dilakukan Irawan, A (2001) yang menyatakan bahwa pengalaman melaut dibutuhkan oleh nelayan namun pengaruhnya tidak nyata terhadap curahan waktu kerja dalam usaha perikanan.

\section{c. Jumlah Tanggungan Keluarga}

Koefisien regresi variabel jumlah tanggungan keluarga bernilai negatif yaitu $-2,871$ hal ini berarti bila jumlah tanggungan bertambah satu satuan maka dapat mempengaruhi penurunan alokasi waktu kerja dalam sektor perikanan tangkap sebesar 2,871 dengan asumsi faktor lain tetap. Namun pengaruh penurunan tersebut tidak nyata, hal ini ditunjukkan oleh nilai t hitung $(0,695)<\mathrm{t}$ tabel $(2,052)$ sehingga terima Ho.

Tidak berpengaruh nyatanya jumlah tanggungan keluarga dikarenakan tidak ada anggota keluarga yang ikut membantu kegiatan penangkapan ikan yang dilakukan di laut.

\section{d. Modal Dalam Sektor Perikanan Tangkap}


Koefisien regresi variabel modal dalam sektor perikanan tangkap bernilai positif yaitu 0,700 hal ini berarti bila modal kerja bertambah satu satuan maka dapat mempengaruhi peningkatan alokasi waktu kerja dalam sektor perikanan tangkap sebesar 0,700 dengan asumsi faktor lain tetap. Pengaruh peningkatan tersebut nyata, hal ini ditunjukkan oleh nilai $t$ hitung $(13,612)>t$ tabel $(2,052)$ sehingga terima Ha.

Kecenderungan dalam melakukan perluasan daerah operasi sangat ditentukan oleh besar kecilnya modal kerja yang dimiliki. Sehingga waktu kerja yang dicurahkan untuk kegiatan penangkapan ikan akan bertambah. Hasil penelitan ini sejalan dengan penelitian yang dilakukan oleh Irawan, A (2001) yang menyatakan bahwa ketersediaan modal kerja untuk operasi penangkapan ikan sangat mendorong nelayan untuk mencurahkan tenaga kerjanya secara maksimal. Dengan demikian maka waktu kerjanyapun akan bertambah seiring dengan optimalisasi modal kerja tersebut.

\section{e. Pengalaman Melaut}

Koefisien regresi variabel pengalaman melaut bernilai negatif yaitu $-3,675$ hal ini berarti bila pengalaman melaut bertambah satu satuan maka dapat mempengaruhi penurunan alokasi waktu kerja dalam sektor perikanan tangkap sebesar 3,675 dengan asumsi faktor lain tetap. Namun pengaruh penurunan tersebut tidak nyata, hal ini ditunjukkan oleh nilai t hitung $(0,546)<\mathrm{t}$ tabel $(2,052)$ sehingga terima Ho.

Kecakapan dalam menangkap ikan ini menjadikan nelayan paham betul dimana daerah operasi yang cocok pada saat-saat tertentu. Memang pengalaman dibutuhkan oleh nelayan, namun hal ini pengaruhnya sangat kecil dalam menurunkan alokasi waktu kerja nelayan. Hasil ini sejalan dengan penelitian yang dilakukan Irawan, A (2001) yang menyatakan bahwa pengalaman melaut dibutuhkan oleh nelayan namun pengaruhnya tidak nyata terhadap curahan waktu kerja dalam usaha perikanan. 


\section{f. Jumlah Tanggungan Keluarga}

Koefisien regresi variabel jumlah tanggungan keluarga bernilai negatif yaitu $-2,871$ hal ini berarti bila jumlah tanggungan bertambah satu satuan maka dapat mempengaruhi penurunan alokasi waktu kerja dalam sektor perikanan tangkap sebesar 2,871 dengan asumsi faktor lain tetap. Namun pengaruh penurunan tersebut tidak nyata, hal ini ditunjukkan oleh nilai t hitung

$(0,695)<\mathrm{t}$ tabel $(2,052)$ sehingga terima Ho.

Tidak berpengaruh nyatanya jumlah tanggungan keluarga dikarenakan tidak ada anggota keluarga yang ikut membantu kegiatan penangkapan ikan yang dilakukan di laut.

\section{g. Modal Dalam Sektor Perikanan Tangkap}

Koefisien regresi variabel modal dalam sektor perikanan tangkap bernilai positif yaitu 0,700 hal ini berarti bila modal kerja bertambah satu satuan maka dapat mempengaruhi peningkatan alokasi waktu kerja dalam sektor perikanan tangkap sebesar 0,700 dengan asumsi faktor lain tetap. Pengaruh peningkatan tersebut nyata, hal ini ditunjukkan oleh nilai t hitung $(13,612)>\mathrm{t}$ tabel $(2,052)$ sehingga terima Ha.

Kecenderungan dalam melakukan perluasan daerah operasi sangat ditentukan oleh besar kecilnya modal kerja yang dimiliki. Sehingga waktu kerja yang dicurahkan untuk kegiatan penangkapan ikan akan bertambah. Hasil penelitan ini sejalan dengan penelitian yang dilakukan oleh Irawan, A (2001) yang menyatakan bahwa ketersediaan modal kerja untuk operasi penangkapan ikan sangat mendorong nelayan untuk mencurahkan tenaga kerjanya secara maksimal. Dengan demikian maka waktu kerjanyapun akan bertambah seiring dengan optimalisasi modal kerja tersebut.

\section{Analisis Faktor-Faktor Yang Mempengaruhi Alokasi Waktu Kerja Nelayan \\ Luar sektor Perikanan Tangkap}


Hasil analisis regresi faktor-faktor yang mempenagruhi alokasi waktu kerja nelayan diluar sektor perikanan tangkap ditunjukkan pada Tabel 8 :

Tabel 8. Hasil Analisis Regresi Liniear Berganda

\begin{tabular}{lccc}
\hline \multicolumn{1}{c}{ Variabel Bebas } & Koefisien Regresi & $\begin{array}{c}\text { Standar } \\
\text { Error }\end{array}$ & T-hitung \\
\hline Umur (ln X1) & 0,212 & 0,247 & 0,861 \\
Pengalaman Mengolah Ikan (ln X2) & $-0,217$ & 0,091 & $-2,388^{*}$ \\
Jumlah Tanggungan Keluarga (ln X3) & $-3,982$ & 0,072 & $-0,056$ \\
Modal Luar Sektor Perikanan (ln X4) & 0,999 & 0,120 & $8,299^{*}$ \\
\hline Intersep & $-10,466$ & & \\
$\mathrm{R}^{2}$ & 0,838 & & \\
T tabel $(27, \alpha / 2,=0,025)$ & 2,052 & & \\
F hitung & 35,034 & & \\
F tabel $(27,4, \alpha=0,05)$ & 2,73 & & \\
\hline
\end{tabular}

Sumber : Analisis Data Primer

Ket $*$ Nyata pada taraf kepercayaan $95 \%$.

Dari hasil estimasi diatas, dapat ditulis suatu persamaan regresi sebagai berikut :

$\operatorname{Ln} Y=-10,466+0,212 \operatorname{Ln} X 1-0,217 \operatorname{Ln} X 2-3,982 \operatorname{LnX} 3+0,999 \operatorname{LnX} 4+\mathrm{U} 2$

$$
(0,247) \quad(0,091)(0,072) \quad(0,120)
$$

Nilai $\mathrm{R}^{2}$ sebesar 0,838 artinya variasi dari naik turunnya alokasi waktu kerja diluar sektor perikanan tangkap dapat dijelaskan secara bersama-sama oleh umur (X1), pengalaman mengolah ikan (X2), jumlah tanggungan keluarga (X3) dan modal kerja luar sektor perikanan tangkap (X4) sebesar 83,8 persen sedangkan sisanya sebesar 16,2 persen dijelaskan oleh variabel lain yang tidak dimasukkan dalam model persamaan regresi ini.

Hasil uji $\mathrm{F}$ menunjukkan $\mathrm{F}_{\text {-hitung }}$ lebih besar dari $\mathrm{F}_{\text {-tabel }}(35,034>2,73)$ sehingga Ho ditolak. Ini artinya secara bersama-sama variabel bebas berpengaruh nyata terhadap alokasi waktu kerja diluar sektor perikanan tangkap. Untuk uji t adalah sebagai berikut :

\section{a. Umur}

Hasil estimasi menunjukkan koefisien regresi variabel umur bernilai positif yaitu 0,212 hal ini berarti bila umur meningkat satu satuan maka akan mempengaruhi peningkatan alokasi waktu kerja diluar sektor perikanan tangkap sebesar 0,212 dengan asumsi faktor 
lain tetap. Namun pengaruh peningkatan tersebut tidak nyata, hal ini ditunjukkan oleh nilai $\mathrm{t}$ hitung $(0,861)<\mathrm{t}$ tabel $(2,052)$ sehingga terima Ho.

Tidak berpengaruh nyatanya umur terhadap alokasi waktu kerja luar perikanan tangkap dikarenakan pekerjaan mengolah ikan kering yang digeluti oleh nelayan sebagai pekerjaan sampingan tidak menuntut patokan umur tertentu bagi mereka yang akan melakukan pengolahan tersebut. Selain itu proses pengolahan ikan basah ini sangat sederhana, sehingga umur tidak menjadi patokan.

\section{b. Pengalaman Mengolah ikan}

Hasil estimasi menunjukkan koefisien regresi variabel pengalaman mengolah ikan bernilai negatif nyaitu $-0,217$ hal ini berarti bila pengalaman mengolah ikan meningkat satu satuan maka akan mempengaruhi penurunan alokasi waktu kerja diluar sektor perikanan tangkap (mengolah ikan) sebesar 0,217 dengan asumsi faktor lain tetap. Pengaruh penurunan tersebut nyata, hal ini ditunjukkan oleh nilai $t$ hitung $(-2,388)<\mathrm{t}$ tabel $(-2,052)$ sehingga terima Ha.

Pengalaman kerja ini memang sangat dibutuhkan, karena semakin banyak pengalaman maka seseorang akan menjadi ahli dan terampil, sehingga alokasi waktu kerja yang dicurahkan dalam sektor ini juga akan semakin berkurang.

\section{c. Jumlah Tanggungan Keluarga}

Koefisien regresi variabel jumlah tanggungan keluarga bernilai negatif yaitu $-3,982$ hal ini berarti bila jumlah tanggungan keluarga meningkat satu satuan maka dapat mempengaruhi penurunan olokasi waktu kerja luar sektor perikanan tangkap sebesar 3,982 dengan asumsi faktor lain tetap. Namun pengaruh penurunan tersebut tidak nyata, hal ini ditunjukkan oleh nilai thitung $(-0,056)<\mathrm{t}$ tabel $(2,052)$ sehingga terima Ho. 
Tidak berpengaruh nyatanya jumlah tanggungan keluarga terhadap alokasi waktu kerja yang dicurahkan untuk mengolah ikan kering dalam penelitian ini dikarenakan anggota keluarga tidak mau berpartisipasi aktif dalam proses pengolahan ini.

\section{d. Modal Luar Perikanan Tangkap}

Koefisien regresi variabel modal kerja bernialai positif yaitu 0,999 hal ini berarti bila modal kerja bertambah satu satuan maka dapat mempengaruhi peningkatan alokasi waktu kerja luar sektor perikanan tangkap sebesar 0,999 dengan asumsi faktor lain tetap. Pengaruh peningkatan tersebut nyata, hal ini ditunjukkan oleh nilai t hitung $(8,299)<\mathrm{t}$ tabel $(2,052)$ sehingga terima Ha.

Berpengaruhnya variabel modal luar sektor perikanan tangkap (mengolah ikan kering) ini dikarenakan ketersediaan modal kerja menyebabkan nelayan lebih banyak membeli ikan basah. Jadi dengan jumlah bahan baku yang lebih banyak maka menyebabkan alokasi waktu kerja untuk mengolah ikan tersebut juga akan meningkat. Hasil ini tidak sejalan dengan penelitian yang dilakukan oleh Irawan, A (2001) yang menyatakan bahwa peranan modal kerja sangat kecil dalam penentuan sikap nelayan untuk mencurahkan waktunya diluar usaha perikanan. Namun sejalan dengan penelitian yang dilakukan oleh Marlina, B (2001) yang menyatakan bahwa dengan banyaknya bahan baku maka semakin bertambah pula alokasi waktu kerja nelayan dalam mengolahnya.

\section{Kontribusi Alokasi Waktu Kerja Dalam Sektor Perikanan Tangkap Dan Luar Sektor Perikanan Tangkap}

Jumlah jam kerja dalam sektor perikanan tangkap yaitu sebesar 4234 jam/bln. Rata-rata alokasi waktu kerjanya adalah sebesar 132,31 jam/bln dengan kisaran 84 jam/bulan hingga $216 \mathrm{jam} / \mathrm{bulan}$ 
Total jam kerja yang curahkan diluar sektor perikanan tangkap yaitu sebesar 3123 jam/bln. Hasil penelitian menunjukkan bahwa rata-rata alokasi waktu kerja nelayan luar sektor perikanan tangkap (mengolah ikan) yaitu sebesar 97,593 jam/bulan dengan kisaran antara $60 \mathrm{jam} / \mathrm{bulan}$ hingga $162 \mathrm{jam} / \mathrm{bln}$.

Untuk melihat besarnya kontribusi waktu kerja dapat dijelaskan oleh Tabel 9

Tabel. 9 Kontribusi Alokasi Waktu Kerja Dalam Perikanan Tangkap Dan Luar Perikanan

\begin{tabular}{lcccc}
\hline No & Jenis Pekerjaan & Total jam/bulan & Rata-rata & Kontribusi (\%) \\
\hline 1 & Menangkap ikan di laut & 4234 & 132,31 & 57,55 \\
2 & Mengolah ikan kering & 3123 & 97,593 & 42,45 \\
\hline & Jumlah & 7357 & 229,903 & 100
\end{tabular}

Sumber : Analisis Data Primer

Dari Tabel diatas dapat dilihat besarnya kontribusi waktu kerja nelayan di dalam sektor perikanan tangkap adalah sebesar 57,55 persen. Sementara kontribusi waktu kerja nelayan diluar perikanan tangkap yaitu mengolah sebagian ikan dari hasil tangkapan adalah sebesar 42,45 persen.

\section{Kontribusi Pendapatan Dalam Sektor Perikanan Tangkap Dan Luar Sektor Perikanan Tangkap}

Total pendapatan dalam sektor perikanan tangkap adalah sebesar Rp 43.435.034,81/bulan. Rata-rata pendapatan dalam sektor perikanan tangkap adalah sebesar Rp 1.357.344,84/bulan dengan kisaran antara $\mathrm{Rp} 709.888,89 /$ bulan hingga $\mathrm{Rp}$ 1.946.964,29/bulan.

Total pendapantan dari bekerja diluar sektor perikanan tangkap (mengolah ikan) adalah sebesar Rp 20.589.129,-/bulan rata-rata pendapatan perbulannya adalah $\mathrm{Rp} 643.410$,/bulan dengan kisaran antara Rp 213.967,-/bulan hingga Rp 1.572.792,-/bulan. 
Adapun untuk melihat besarnya kontribusi pendapatan diluar sektor perikanan tangkap dapat dijelaskan oleh Tabel 10 berikut :

Tabel. 10 Kontribusi Pendapantan Didalam Perikanan Tangkap Dan Luar Perikanan

\begin{tabular}{ccccc}
\hline No & Jenis Pekerjaan & Total Pendapatan/bulan & Rata-rata & Kontribusi (\%) \\
\hline 1 & Menangkap ikan di laut & $43.435 .034,81$ & $1.357 .344,-$ & 67,84 \\
2 & Mengolah ikan kering & 20.589 .129 & 643.410 & 32,16 \\
\hline & Jumlah & $64.024 .163,81$ & 2.000 .754 & 100
\end{tabular}

Sumber : Analisis Data Primer

Dari Tabel 10 diatas dapat dilihat kontribusi pendapatan nelayan dari bekerja didalam sektor perikanan tangkap adalah sebesar 67,84 persen. Sementara kontribusi pendapatan nelayan dari bekerja diluar sektor perikanan tangkap adalah sebesar 32,16 persen.

\section{KESIMPULAN DAN SARAN}

\section{Kesimpulan}

1. Faktor yang berpengaruh nyata terhadap alokasi waktu kerja nelayan didalam sektor perikanan tangkap adalah modal.

2. Faktor-faktor yang berpengaruh nyata terhadap alokasi waktu kerja nelayan diluar sektor perikanan tangkap adalah pengalaman kerja dan modal.

3. kontribusi alokasi waktu kerja nelayan dalam sektor perikanan tangkap lebih besar dibandingkan dari luar sektor perikanan tangkap, masing-masing kontribusi alokasi waktu kerja tersebut adalah sebesar 57,55 persen dan 42,45 persen.

4. kontribusi pendapatan nelayan dalam sektor perikanan tangkap lebih besar dibandingkan dari luar sektor perikanan tangkap, masing-masing kontribusi pendapatan tersebut adalah sebesar 67,84 persen dan 32,16 persen.

\section{Saran}


Nelayan yang mempunyai modal yang cukup besar baik yang dialokasikan didalam sektor perikanan tangkap maupun diluar sektor perikanan tangkap, hendaklah memanfaatkan modal tersebut dengan sebaik mungkin, karena modal sangat berpengaruh untuk mendorong meningkatkan pendapatan. Artinya nelayan masih dapat meningkatkan pendapatannya dengan jalan menambah penggunaan faktor modal ini, baik didalam maupun diluar sektor perikanan tangkap.

\section{DAFTAR PUSTAKA}

Drapper, NR. 1992. Analisis Regresi Terapan. Ed. Kedua. Gramedia : Jakarta

Gujarati, D. 1978. Ekonometrika Dasar. Penerbit Erlangga : Jakarta

Irawan, A dan Nurung, M. 2001. Analisa Alokasi Waktu Kerja Dan Pendapatan Rumah Tangga Nelayan Dalam Kegiatan Ekonomi (Studi Kasus Di Kotamadya Bengkulu). Laporan lembaga penelitian UNIB

Marlina, B. 2003. Analisis Agribisnis, Nilai Tanbah Dan Pemasaran Agribisnis Perikanan Di Desa Pasar Ipuh Mukomuko Selatan. Skripsi. FP-UNIB (Tidak dipublikasikan).

Nazir, M. 1988. Metodologi Penelitian. Ghalia Indonesia : Jakarta

Nikijuluw. V.P.H. 2002. Rezim Pengelolaan Sumberdaya Perikanan. PT. Pustaka Cidesido : Jakarta

Pramudyasmoro, H.B. 1993. Faktor-Faktor Yang Mempengaruhi Rendahnya Tingkat Kesejahteraan Keluarga Nelayan di Bengkulu. Laporan Lembaga Penelitian UNIB : Bengkulu.

Supranto, J. 1990. Ekonometrik. Lembaga Penerbit Fakultas Ekonomi UI : Jakarta 